\title{
ВЫДЕЛЕНИЕ БЕТУЛИНА ИЗ БЕРЕСТЫ БЕРЕЗЫ И ИЗУЧЕНИЕ ЕГО ФИЗИКО-ХИМИЧЕСКИХ И ФАРМАКОЛОГИЧЕСКИХ СВОЙСТВ
}

\author{
() С.А. Кузнецова ${ }^{1,2 * *}$, Г.П. Скворцова ${ }^{1}$, Ю.Н. Маляр ${ }^{I}$, Е.С. Скурыдина ${ }^{I}$, О.Ф. Веселова ${ }^{3}$ \\ ${ }^{1}$ Институт химии и химической технологии СО РАН, Академгородок, 50/24, \\ Красноярск, 660049 (Россия), e-mail:ksa@icct.ru \\ ${ }^{2}$ Сибирский феедеральный университет, пр. Свободный, 79, Красноярск, \\ 660041 (Россия) \\ ${ }^{3}$ Красноярский государственный медицинский университет, Партизана \\ Железняка, 1, Красноярск, 660022 (Россия)
}

\begin{abstract}
Получены бетулинсодержащие продукты с выходом около $40 \%$ от массы а.с.б. и содержанием бетулина в них 74-75\% и 85-89\%, в присутствии гидроксида натрия и калия соответственно. Представлен одностадийный способ выделения бетулина высокой степени чистоты - 97,7\%. Бетулин идентифицирован с использованием физико-химических методов: элементного анализа, ИК- и ЯМР-спектроскопии, электронно-сканирующей микроскопии, изучены термические характеристики бетулина.

Показано, что бетулин проявляет гастропротекторные, гепатопротекторные и капилляроукрепляющие свойства.

Ключевые слова: береста коры берёзы, бетулин, гидроксид натрия, гидроксид калия, гастропротекторные, гепатопротекторные, капилляроукрепляющие свойства.
\end{abstract}

Работа поддержана грантом программы РАН «Фундаментальные науки -медицине».

\section{Введение}

Химический состав коры многих видов берез, а именно Betula pendula Roth. (B. Verrucosa Ehrh.), Betula pubescens Ehrh. (B. alba L.), B. davurica Pall., изучен достаточно подробно. Из бересты берез можно извлечь до $40 \%$ экстрактивных веществ. В экстрактах внешней коры различных видов берез преобладают пентациклические тритерпеноиды ряда лупана. Основным компонентом всех экстрактов является бетулин, обусловливающий белый цвет коры берез. Содержание бетулина во внешней коре (бересте) варьируется от 10 до 40\% в зависимости от вида березы, места и условий ее произрастания, возраста дерева, сезона [1-3].

Наружная часть бересты березы давно использовалась для получения берестового дегтя, который применяется в фармакологии и ветеринарии, как антисептик и противочесоточное средство. Береста в народной медицине сама по себе также использовалась в качестве антисептика при лечении гнойных ран и различных кожных заболеваний. Велер отметил антисептические свойства бетулина, его использовали для

Кузнецова Светлана Алексеевна - ведущий научный сотрудник, доктор химических наук, профессор, тел./факс: (391) 249-54-81, e-mail: ksa@icct.ru Сквориова Галина Павловна - научный сотрудник, тел.: (391) 249-48-93, e-mail: ksa@icct.ru Маляр Юрий Николаевич - аспирант, тел.: (391) 249-54-81

Скурыдина Евгения Сергеевна - аспирант, тел.: (391) 249-54-81

Веселова Ольга Федоровна - доцент, кандидат медицинских наук стерилизации пластырей и бинтов [4]. Бетулин наносили для снятия зуда [5].

Впервые бетулин был извлечен сублимацией из бересты берёзы последователем Михаила Ломоносова Товиасом Ловицем в 1788 г. В последние десятилетия появилось много работ, посвященных как способам получения бетулина, так и его фармакологическим свойствам [6-17].

\footnotetext{
* Данная статья имеет электронный дополнительный материал (приложение), который доступен читателям журнала по адресу: http://www.chem.asu.ru/chemwood/volume17/2013_02/1302-093.pdf. DOI: 10.14258/jcprm.201302093s.

*** Автор, с которым следует вести переписку.
} 
Бетулин обладает антисептическими, антивирусными (вирус герпеса и Эпштейн-Барра), противовоспалительными, гепатопротекторными, антиоксидантными и другими свойствами. Цитотоксическая активность производных бетулина исследована по отношению к различным раковым клеткам. Наиболее выраженной противоопухолевой активностью обладает бетулиновая кислота, являющаяся селективным ингибитором роста клеток меланомы человека, ингибитором роста раковых клеток [6-8].

Известные методы выделения бетулина основаны на экстракции бересты березы органическими растворителями, щелочном гидролизе бересты с последующей экстракцией гидролизата низшими алифатическими спиртами, экстракции органическими растворителями с последующей обработкой экстракта раствором щелочи, а также использование вышеперечисленных методов для предварительно активированной бересты [9-18].

Однако бетулин плохо растворим в большинстве растворителей, что обусловливает невысокую степень его извлечения. Бетулин растворим в пиридине, тетрагидрофуране, диметилсульфоксиде. В спиртовых растворителях растворимость бетулина уменьшается в ряду: 1-бутанол >1-пропанол > этанол $>1$-пентанол $>$ 1-гексанол > метанол. Растворимость бетулина в эфирах уменьшается в следующем порядке: этилацетат $>$ метилацетат $>$ этилформиат $=$ метилформиат $[1,19]$.

Гидролиз бересты березы проводят растворами щелочей: гидроксида натрия или гидроксида калия. В процессе кипячения бересты в водно-спирто-щелочном растворе происходит омыление жиров, восков, а также перевод других экстрактивных веществ, включая фенолы и полифенолы, в растворимое в водной щелочи состояние. Так, например, гидролиз измельченной бересты проводят в 15-25\%-ных растворах гидроксида натрия или гидроксида калия в течение 1-2 ч [12]. Бетулин выделяют из гидролизованной бересты экстракцией низшими алифатическими спиртами - метиловым, этиловым или изопропиловым. Выход бетулина из бересты гидролизованной кипячением в гидроксиде натрия составляет $32,3 \%$ с чистотой $98 \%$, а в гидроксиде калия - 32,7\% с чистотой $99 \%$ [13]. В работе [16] предложен способ одновременно щелочного гидролиза бересты березы гидроксидом натрия или гидроксидом калия и экстракции изопропиловым спиртом в течение 3 ч. После многократной перекристаллизации сухих продуктов получен бетулин с чистотой $96,4 \%$ и выходом $16 \%$ от массы а.с.б. при гидролизе гидроксидом натрия, и чистотой 96,7\% и выходом $18 \%$ от массы а.с.б. при гидролизе гидроксидом калия.

Поскольку бетулин обладает широким спектром биологической активности, а также является исходным веществом для синтеза многих его производных, актуальной задачей является совершенствование методов его извлечения из бересты березы. Ранее в наших работах были описаны также некоторые протестированные фармакологические свойства экстрактов бересты [20, 21].

Цель данной работы - подбор условий выделения бетулина из бересты коры березы Betula pendula Roth. и изучение его фармакологических свойств в экспериментах in vivo.

\section{Экспериментальная часть}

Методика получения бетулина из бересты березы. Выделение бетулина проводили из измельченной бересты березы Betula pendula Roth. фракции 2-5 мм на водяной бане при температуре кипения, равной $80^{\circ} \mathrm{C}$.

Способ 1. В круглодонную колбу объемом 2000 мл, снабженную обратным холодильником, помещали 30 г воздушно-сухой бересты березы, добавляли 1000 мл 96\%-го этилового спирта и раствор щелочи. Концентрация щелочи в водном растворе варьировалась от 5 до $35 \%$ мас. Затем реакционную смесь кипятили на водяной бане в течение 2-8 ч. После кипячения реакционную массу быстро отфильтровывали от остатков негидролизованной бересты на воронке Бюхнера. Из полученного фильтрата этанол отгоняли простой перегонкой при атмосферном давлении. На следующий день остаток после отгонки этанола отфильтровывали на воронке Бюхнера, промывали дистиллированной водой до нейтральной реакции. Полученный продукт выгружали, сушили при комнатной температуре, определяли выход и температуру плавления.

Перекристаллизацию продукта проводили из этанола или изопропанола. В круглодонную колбу объемом 2000 мл, снабженную обратным холодильником, загружали навеску продукта 10 г, 1000 мл этилового или изопропилового спирта и кипятили на водяной бане до полного его растворения. Затем горячий раствор отфильтровали через бумажный фильтр на воронке Бюхнера. Полученный фильтрат охлаждали и оставляли для кристаллизации бетулина. На следующий день бетулин (1), выпавший в осадок, отфильтровывали и сушили при комнатной температуре. Из фильтрата отгоняли $2 / 3$ объема спирта и оставляли для 
кристаллизации из него бетулина. Полученный бетулин (2) также сушили при комнатной температуре. Затем смешивали бетулин (1) и (2), определяли их суммарный выход и температуру плавления.

Способ 2. Для получения бетулина высокой степени чистоты в круглодонную колбу объемом 2000 мл, снабженную обратным холодильником, помещали 50 г воздушно-сухой бересты березы, добавляли 1500 мл 96\%-ного этилового спирта и раствор щелочи, приготовленный растворением навески 90 г $\mathrm{KOH}$ в 350 мл воды. После кипячения реакционную массу быстро отфильтровывали от остатков негидролизованной бересты на воронке Бюхнера. Полученный фильтрат оставляли на ночь для кристаллизации бетулина. На следующий день осадок отфильтровывали на воронке Бюхнера, промывали дистиллированной водой до нейтральной реакции. Полученный продукт выгружали и высушивали при комнатной температуре, определяли выход и температуру плавления. Из полученного фильтрата регенерировали этиловый спирт простой перегонкой при атмосферном давлении.

Физико-химические исследования продукта. Анализ продуктов щелочного гидролиза бересты проводили на жидкостном микроколоночном хроматографе «Миллихром А-02» со спектрофотометрическим сканирующим детектором УФ-диапазона («ЭкоНова», Новосибирск).

В качестве неподвижной фазы использовали колонку из нержавеющей стали ProntoSIL-120-5-C18 AQ размером 2,0×75 мм с зернением 5,0 мкм. Подвижная фаза: ацетонитрил - деионизированная вода (86 : 14), скорость подачи элюента 200,0 мкл/мин, температура колонки $35{ }^{\circ} \mathrm{C}$, дозируемый объем пробы 4,0 мкл, время регистрации хроматограммы 6 мин. Расчет содержания определяемого компонента проводили по ВЭЖХ хроматограммам методом внешнего стандарта с применением программы «МультиХромСПЕКТР» для Windows (Ampersand Ltd.).

Элементный состав продукта определен на элементном анализаторе FLASH ${ }^{\mathrm{TM}} 1112$.

ЯМР-спектроскопическое исследование бетулина было произведено на спектрометре Bruker DPX200 при частоте $200 \mathrm{MHz}=\left({ }^{1} \mathrm{H}\right)$, растворитель $-\mathrm{CDCl}_{3}$.

Регистрацию ИК-спектров проводили на ИК-Фурье спектрометре Vektor 22 в области длин волн 4000-400 $\mathrm{cm}^{-1}$. Обработку спектральной информации проводили с использованием пакета программ OPUS, версия 5.0. Образец для съемки ИК-спектра поглощения готовили в виде таблетки в матрице бромида калия. Концентрация вещества составляет 3 мг вещества/ 1000 мг $\mathrm{KBr}$.

Термогравиметрические исследования проводили на синхронном термоанализаторе STA 449C Jupiter, совмещенном с масс-спектрометром QMS 403C Aeols (фирма NETSCH). Навеску перекристаллизованного из этанола бетулина 4 мг нагревали в алюминиевом тигле от 40 до $600{ }^{\circ} \mathrm{C}$ при скорости нагрева $10{ }^{\circ} \mathrm{C} /$ мин в токе аргона.

Методики изучения фармакологических свойств бетулина. Для изучения гастропротекторных свойств бетулина на модели индометациновой язвы в хроническом эксперименте были взяты группы мышей массой 10-12 г по 10 особей. Бетулин вводили в виде 1,5\% крахмальной взвеси внутрижелудочно, однократно утром в течение 7 дней подряд в дозе 600 мг/кг. Контрольной группе вводили воду по 0,2 мл / 100 г веса. Последнее введение препарата производили за 1 час до воспроизведения язвы. Язвообразование индуцировали путем внутрижелудочного введения индометацина в дозе 20 мг/кг. Через сутки животных подвергали эвтаназии под эфирным наркозом, подсчитывали количество язвенных поражений во всех группах и рассчитывали индекс Паулса по формуле: ИП = (А·B)/100, где А - среднее количество язв на одно животное, В - количество животных с язвами в группе. Противоязвенную активность (ПА) определяли как отношение ИП контрольной группы к ИП опытных.

Изучение гепатопротекторных свойств бетулина проводили на модели лекарственного гепатита. Модель парацетамолового гепатита воспроизводили у 18 мышей путем введения в желудок в течение 2 дней водного парацетамола в дозе 1 г/кг массы тела (0,2 мл/100 г). Опытной группе мышей бетулин вводили в желудок в виде 1,5\% крахмальной взвеси в дозе 600 мг/кг за час до введения парацетамола. В сыворотке крови животных определяли активность аланинаминотрансферазы (АЛТ), аспартатаминотрансферазы (АСТ), щелочной фосфотазы (ЩФ), уровень общего билирубина (БИЛ).

Изучение влияния бетулина на проницаемость сосудов кожи проводили по методу Ойвина и Монаковой на мышах массой 10-12 г. Критерием сосудистой проницаемости служило время выхода 1\% водного метиленового синего в очаг воспаления, вызываемого нанесением на депилированную поверхность кожи 0,05 мл ксилола. Опытным группам мышей за 1 ч до внутрибрюшинного введения 0,25 мл $1 \%$ раствора метиленового синего внутрижелудочно вводили бетулин в дозе 200 и 400 мг/кг в виде $1 \%$ спиртового рас- 
твора. Контрольной группе мышей за 1 ч до введения раствора, метиленового синего вводили этиловый спирт. Регистрировали время выделения метиленового синего в очаге воспаления. Эталоном сравнения служил дигидрокверцетин (ДКВ), капилляроукрепляющий эффект которого известен.

\section{Результаты и обсуждение}

Влияние природы и концентрации щелочи на выход бетулинсодержащих продуктов и содержание 8 них бетулина. С целью снижения концентрации щелочи в растворе и повышения выхода бетулина были совмещены стадии щелочного гидролиза и экстракции бетулина этанолом, что достигается при обработке бересты водно-этанольно-щелочной смесью. Было установлено, что для полного извлечения бетулина из бересты необходимо кипячение 8 ч. Результаты проведенных экспериментов представлены в таблице 1.

В процессе кипячения бересты в водно-этанольно-щелочных растворах происходит омыление субериновых кислот, жиров, восков, а также перевод многих других экстрактивных веществ, включая фенолы и полифенолы (танниды, флавоноиды), жирные и тритерпеновые кислоты, в раствор.

В таблице 1 приведено содержание бетулина в бетулинсодержащих продуктах (данные ВЭЖХ), в зависимости от концентрации гидроксидов натрия и калия в водно-этанольно-щелочном растворе. Из таблицы 1 видно, что при экстракции бересты березы водно-этанольными растворами гидроксида натрия и гидроксида калия при изменении концентрации щелочи в растворе от 5 до 35\% выход бетулинсодержащих продуктов варьируется от 34,3 до $43,1 \%$ и от 32,5 до $39,1 \%$ от массы а.с.б. соответственно. А массовая доля бетулина в продуктах варьируется от 62,7 до $75,3 \%$ при использовании гидроксида натрия и от 79,3 до $89,3 \%$ в присутствии гидроксида калия.

Таким образом, при использовании водных растворов гидроксида натрия и калия концентрации от 10 до $25 \%$ в водно-этанольно-щелочных растворах получены бетулинсодержащие продукты с выходом около $40 \%$ от массы а.с.б. и содержанием в них бетулина 74-75 и 85-89\%, соответственно.

После перекристаллизации из этилового или изопропилового спирта чистота продукта составила $96,0 \%$, температура его плавления $-257^{\circ} \mathrm{C}$.

Получение бетулина высокой степени чистоты. При получении бетулина по способу 1 было обнаружено, что при охлаждении фильтрата, после удаления негидролизованной бересты, образуется бетулин. Поэтому предложен быстрый способ извлечения бетулина из бересты без предварительной отгонки этилового спирта и дополнительной перекристаллизации продукта, но с меньшим выходом по способу 2. Выход бетулина составляет $28,5 \%$ от массы а.с.б., а чистота $97,7 \%$, от массы а.с.п.

Физико-химические исследования бетулина. Для подтверждения структуры перекристаллизованного бетулина были использованы физико-химические методы: электронно-сканирующая микроскопия, элементный анализ, ИК- и ЯМР-спектроскопия.

В электронном приложении к статье (рис. 1) представлены электронно-сканирующие изображения неперекристаллизованного продукта гидролиза бересты водно-спирто-щелочным раствором, бетулина перекристаллизованного из этанола и из изопропанола. Кристаллы всех трех продуктов имеют игольчатую форму. Размер кристаллов неперекристаллизованного продукта щелочного гидролиза бересты составляет от 3 до 20 мкм, размер кристаллов бетулина перекристаллизованного из этанола - от 10 до 100 мкм, размер кристаллов бетулина перекристаллизованного из изопропанола - от 25 до 150 мкм.

Таблица 1. Влияние концентрации щелочи на выход бетулинсодержащих продуктов и содержание в них бетулина

\begin{tabular}{c|c|c|c|c|c}
\hline \multirow{2}{*}{$\begin{array}{c}\text { № } \\
\text { образца }\end{array}$} & $\begin{array}{c}\text { Концентрация } \\
\text { щелочи, \% мас. }\end{array}$ & \multicolumn{2}{|c|}{ Выход продукта, \% от массы а.с.б. } & \multicolumn{2}{c}{ Содержание бетулина, \% от массы продукта } \\
\hline 1 & 5 & NaOH & KOH & КаOH & КОН \\
\hline 2 & 10 & 34,3 & 32,5 & 62,7 & 79,3 \\
3 & 15 & 39,4 & 38,0 & 73,7 & 85,3 \\
4 & 20 & 43,8 & 37,4 & 74,0 & 86,2 \\
5 & 25 & 41,5 & 36,7 & 75,3 & 89,3 \\
6 & 30 & 42,9 & 39,1 & 73,1 & 88,5 \\
7 & 35 & 41,9 & 38,7 & 74,2 & 88,3 \\
\hline
\end{tabular}


По данным элементного анализа найдено, \%: (C) 81,9; (H) 11,5; (O) 7,9. Вычислено, \%: (C) 81,4; (H) 11,$3 ;(\mathrm{O}) 7,2$.

${ }^{1} \mathrm{H}$ ЯМР-спектр (растворитель $\mathrm{CDCl}_{3}$ ) содержит следующие сигналы: $\delta$ 4,68 (м, $\left.1 \mathrm{H}, 29-\mathrm{H}\right), 4,58$ (м, $1 \mathrm{H}, 29-\mathrm{H}), 3,81$ (д, 1 H, 28-H), 3,35 (д, $1 \mathrm{H}, 28-\mathrm{H}), 3,14$ (м, 1 H, 3-H), 2,38 (м, 1 H, 19-H), 1,05-2,05 ( $\mathrm{CH}_{2}$, СН-группы), 1,68 (м, 3 H, 30-Н), 1,02, 0,98, 0,97, 0,82, 0,76 (все с, 15 H, 5× $\mathrm{CH}_{3}$ ).

В ИК спектре бетулина наблюдается полоса поглощения, соответствующая валентным колебаниям спиртовой гидроксильной группы $v(\mathrm{O}-\mathrm{H})=3374,32 \mathrm{~cm}^{-1}$. Валентные колебания $\mathrm{C}-\mathrm{H}$ связей $\mathrm{CH}_{2}-г$ рупп проявляются при $v(\mathrm{C}-\mathrm{H})_{\mathrm{as}}=2916,65 \mathrm{~cm}^{-1}, v(\mathrm{C}-\mathrm{H})_{\mathrm{s}}=2850,02 \mathrm{~cm}^{-1}$, для $\mathrm{CH}_{3}$-групп - при $v(\mathrm{C}-\mathrm{H})_{\mathrm{s}}=2887,13 \mathrm{~cm}^{-1}$. Деформационным колебаниям $\mathrm{C}-\mathrm{H}$ связей $\mathrm{CH}_{2}$-групп соответствуют полосы поглощения при $\delta(\mathrm{C}-\mathrm{H})_{\mathrm{as}}=$ $1470,82 \mathrm{~cm}^{-1}$ (плоскостное «ножничное» колебание), для $\mathrm{CH}_{3}$-групп характеристическим является поглощение при $\delta(\mathrm{C}-\mathrm{H})_{\mathrm{s}}=1374,99 \mathrm{~cm}^{-1}$.

Характеристической частотой валентных колебаний двойной связи $\mathrm{R}_{1} \mathrm{R}_{2} \mathrm{C}=\mathrm{CH}_{2}$ является $v(\mathrm{C}=\mathrm{C})=$ $1644,49 \mathrm{~cm}^{-1}$. Пик при $v(\mathrm{C}-\mathrm{H})=3079,84 \mathrm{~cm}^{-1}$ соответствует валентным, а при $\gamma(\mathrm{C}-\mathrm{H})=879,79 \mathrm{~cm}^{-1}$ внеплоскостным деформационным колебаниям $\mathrm{C}-\mathrm{H}$ связей при углероде с двойной связью. Валентное колебание связи С-О определено в области $1075-1000 \mathrm{~cm}^{-1}$ при $v(\mathrm{C}-\mathrm{O})=1028,83 \mathrm{~cm}^{-1}$.

Термические исследования бетулина. Для проведения термических исследований использовали бетулин, перекристаллизованный из этанола. В электронном приложении к статье (рис. 2) представлены термические характеристики бетулина: термогравиметрическая кривая потери массы образца от температуры (TG), дифференциальная термогравиметрическая кривая потери массы образца от температуры (DTG) и кривая дифференциальной сканирующей калориметрии (DSC).

Анализ полученных кривых показывает, что в процессе термических превращений исследуемого образца можно выделить три стадии, характеризующихся наличием на кривой DTG пика в области $135{ }^{\circ} \mathrm{C}$ (первая стадия), пика с максимумом при $409{ }^{\circ} \mathrm{C}$ (вторая стадия) и при $449{ }^{\circ} \mathrm{C}$ (третья стадия). На первой стадии потеря массы образца составила $3,3 \%$, на второй - 81,5\%, на третьей $-14,9 \%$.

Пики потери массы сопровождаются появлением пиков на кривой DSC при соответствующих температурах. Также обнаружены пики, указывающие на наличие эндотермических процессов, протекающих без потери массы. Так, пик с максимумом $207^{\circ} \mathrm{C}$, возможно, связан с плавлением примеси, находящейся в образце, а пик с максимумом $258^{\circ} \mathrm{C}$ вызван плавлением бетулина, что совпадает с приводимой в литературе температурой плавления (от 251 до $261^{\circ} \mathrm{C}$ ).

Изменение состава летучих продуктов термического превращения образца исследовалось методом масс-спектрометрии. Пику потери массы при температуре $135{ }^{\circ} \mathrm{C}$ соответствует резкое увеличение интенсивности масс $\mathrm{M} / \mathrm{Z}=29,31,45$ и 46, являющихся наиболее интенсивными массами в спектре этилового спирта. Согласно кривой DSC процесс потери массы при данной температуре является эндотермическим, то на первой стадии он сопровождается испарением этилового спирта. При этом пик потери массы на кривой DTG проявляется при температуре $135^{\circ} \mathrm{C}$, что значительно превышает температуру кипения этанола $\left(78,3^{\circ} \mathrm{C}\right)$. Полученные данные указывают, что этанол находится в образце в связанном состоянии, возможно в виде сольватов бетулина. Таким образом, потеря массы образцом при температуре $135{ }^{\circ} \mathrm{C}$ с выделением этилового спирта связана с удалением кристаллизованного растворителя из структуры сольватов при его разложении под действием температуры.

На второй стадии пику потери массы при температуре $409{ }^{\circ} \mathrm{C}$ и на третьей при $449{ }^{\circ} \mathrm{C}$ соответствует резкое увеличение интенсивности сигналов масс $\mathrm{M} / \mathrm{Z}=55,69,81,95$, являющихся наиболее интенсивными массами в регистрируемой в настоящей работе области масс-спектра бетулина. Кроме того, на третьей стадии увеличивается интенсивность сигналов масс $M / Z=16$ и 44, которые могут быть отнесены к метану и $\mathrm{CO}_{2}$ соответственно, и $\mathrm{M} / \mathrm{Z}=57,71$, являющихся типичными массами фрагментов нормальных алканов.

Потеря массы на второй стадии обусловлена испарением бетулина. На третьей стадии, кроме испарения бетулина, возможно, происходит испарение веществ с более высокой температурой кипения, находящихся в образце в качестве примесей, и их термическое разложение, о чем свидетельствует экзотермический пик на кривой DSC при соответствующей температуре.

Изучение фармакологических свойств бетулина. На базе Красноярского государственного медицинского университета были проведены исследования по гастро- и гепатопротекторной активности, а также капилляроукрепляющих свойств бетулина. 
Бетулин является нетоксичным веществом: минимальная летальная доза (ЛД16) составляет 6500 мг/кг, среднелетальная (ЛД50) - 9000 мг/кг, поэтому согласно международной токсикологической классификации его можно отнести к 4 классу малотоксичных веществ.

Результаты исследования гастрозащитных свойств бетулина на модели индометациновой язвы желудка представлены в таблице 2.

Противоязвенная активность бетулина составила 9,3, что указывает на эффективное противоязвенное действие бетулина.

Полученные данные свидетельствуют о том, что бетулин и экстракт бересты проявляют высокий гастрозащитный эффект, причем гастропротекторное действие бетулина выше, чем экстракта бересты.

Парацетамол в дозировке 1 г/кг массы тела является гепатотропным ядом и вызывает лавинообразное перекисное окисление липидов бислоя клеточных мембран гепатоцитов. Вследствие этого происходит высвобождение микросомальных и гиалоплазменных ферментов клеток печени и наблюдаются высокие цифры активности аланинаминотрансферазы (АЛТ) и аспартатаминотрансферазы (АСТ) в сыворотке крови животных контрольной группы. Результаты исследования гепатопротекторных свойств бетулина представлены в таблице 3 .

Бетулин достоверно препятствует росту активности АЛТ, чем объясняется снижение этих показателей у опытных групп мышей. Таким образом, проведенные исследования свидетельствуют о гепатопротекторных свойствах бетулина.

Результаты изучения влияния бетулина на проницаемость сосудов кожи мышей представлены в таблице 4. На основании проведенных исследований установлено, что бетулин и экстракт бересты проявляют дозозависимое влияние на проницаемость сосудов. Так, например, при введении дозы этих веществ 400 мг/кг капилляроукрепляющий эффект почти в 3 раза выше, чем для дозы 200 мг/кг, и составлял 146,9\% для бетулина.

Таблица 2. Гастрозащитные свойства бетулина и экстракта бересты на модели индометациновой язвы

\begin{tabular}{l|c|c|c|c|c}
\hline \multicolumn{1}{c|}{ Группы } & Доза, мГ/кг & Общее количество язв & Количество язв на 1 животное & ИП** & ПА** \\
\hline Контроль & - & 28 & 3,5 & 0,28 & - \\
Бетулин & 600 & 6 & $0,75^{*}$ & 0,03 & 9,3 \\
Экстракт бересты & 600 & 10 & 1 & 0,04 & 7
\end{tabular}

Примечания. * p < 0,05 по отношению к контролю (р -вероятность случайности); ** ИП - индекс Паулса, ПА - противоязвенная активность; ИП = AB/100 (А - среднее количество язв на одно животное, В - количество животных с язвами).

Таблица 3. Влияние бетулина и экстракта бересты на биохимические показатели крови на модели лекарственного гепатита

\begin{tabular}{l|c|c|c|c}
\hline \multicolumn{1}{c|}{ Группа } & БИЛ, мкмоль/л & АЛТ, мккат/л & АСТ, мккат/л & ЩФ, ед/л \\
\hline Контроль & $4,32 \pm 0,42$ & $4,38 \pm 0,76$ & $2,59 \pm 0,30$ & $159,88 \pm 34,28$ \\
Бетулин & $3,94 \pm 0,51$ & $2,66 \pm 0,54$ & $2,52 \pm 0,54$ & $169,02 \pm 47,51$ \\
Экстракт бересты & $3,11 \pm 0,51^{*}$ & $1,98 \pm 0,93 *$ & $1,88 \pm 0,45$ & $111,59 \pm 19,95^{*}$ \\
\hline
\end{tabular}

Примечание. * $\mathrm{p}<0,05$ по отношению к контролю.

Таблица 4. Влияние бетулина и экстракта бересты на проницаемость сосудов кожи

\begin{tabular}{l|c|c|c}
\hline \multicolumn{1}{c|}{ Вещество } & Доза, мг/кг & $\begin{array}{c}\text { Время выхода } \\
\text { метиленовой сини, с }\end{array}$ & $\begin{array}{c}\text { Капилляроукрепляющий } \\
\text { эффект, \% от контроля }\end{array}$ \\
\hline Контроль & - & $14,7 \pm 1,5$ & - \\
Бетулин & 200 & $21,7 \pm 3,8^{*}$ & 47,6 \\
& 400 & $36,3 \pm 4,0^{*}$ & 146,9 \\
Экстракт бересты & 200 & $23,7 \pm 3,4^{*}$ & 60,5 \\
Дигидрокверцетин & 400 & $29,8 \pm 4,2^{*}$ & 102,7 \\
& 100 & $21,5 \pm 2,6^{*}$ & 33,9 \\
\hline
\end{tabular}

Примечание. * p < 0,05 по отношению к контролю. 


\section{Выводы}

Подобраны условия получения бетулина из бересты березы с использованием оптимальных концентраций гидроксида натрия и калия в водно-этанольно-щелочных растворах. Получены бетулинсодержащие продукты с выходом около 40\% от массы а.с.б. и содержанием в них бетулина 74-75\% и 85-89\% соответственно.

Представлен одностадийный способ выделения бетулина высокой степени чистоты - 97,7\%.

Бетулин идентифицирован с использованием физико-химических методов: элементного анализа, ИК- и ЯМР-спектроскопии, электронно-сканирующей микроскопии.

Установлены термические характеристики бетулина, согласно которым при температуре $135^{\circ} \mathrm{C}$ происходит испарение этилового спирта из образца, при температуре $258{ }^{\circ} \mathrm{C}$ наблюдается плавление бетулина, при температуре $409{ }^{\circ} \mathrm{C}$ - испарение бетулина, выше температуры $449{ }^{\circ} \mathrm{C}$ - термическое разложение бетулина.

В экспериментах in vivo показано, что бетулин проявляет гастропротекторные, гепатопротекторные и капилляроукрепляющие свойства.

\section{Электронный дополнительный материал}

В электронном приложении приведены фотографии, полученные на электронно-сканирующем микроскопе, и термогравиметрическая кривая.

\section{Список литературы}

1. Кислицин А.Н. Экстрактивные вещества бересты: выделение, состав, свойства, применение // Химия древесины. 1994. №3. С. 3-28.

2. Похилло Н.Д., Уварова Н.И. Изопреноиды различных видов рода Betula // Химия природных соединений. 1988. №3. С. 325-341.

3. Жученко А.Г., Черкасова А.И. Химический состав бересты берез // Сборник трудов СвердНИИП древесины. М., 1969. Вып. 4. С. 6-9.

4. Wheeler J. Die Darstellung des Betulin durch Sublimation // Pharm. J. 1899. N1. Pp. 494.

5. Holmes E.M. Birch tar// Pharm. Jour. 1921. N106. Pp. 508.

6. Толстиков А.Г., Флехтер О.Б., Шульц Э.Э., Балтина Л.А. Бетулин и его производные. Химия и биологическая активность // Химия в интересах устойчивого развития. 2005. №13. С. 1-30.

7. Толстиков Т.Г., Сорокина И.В., Толстиков Г.А. Терпеноиды ряда лупана - биологическая активность и фармакологические перспективы // Биоорганическая химия. 2006. Т. 32, №1. С. 42-55.

8. Matsuda H., Ishikado A., Nishida N. Hepatoprotective, superoxide scavenging and antioxidantive activities of aromatic constituents from the bark of betula platyphylla var. japonica // Bioorganic \& Medicinal Chemistry Letters. 1998. Vol. 8. P. 2939-2944.

9. Абышев А.З., Агаев Э.М., Гусейнов А.Б. Исследование химического состава экстракта коры березы cortex betula cem. Betulaceae // Химико-фармацевтический журнал. 2007. Т. 41, №8. С. 22-26.

10. Jääskelainen P. Betulinol and its utilization // Paperi ja Puu. 1981. Vol. 63, N10. Pp. 599-603.

11. Hayek E.W.H., Jordis U., Moche W., Sauter F. A bicentennial of betulin // Phytochemistry. 1989. Vol. 28 , N2. Pp. 2229-2242.

12. А.с. 382657 (СССР). Способ выделения бетулина и суберина / Т.Н. Федорищев, В.Г. Калайков. 23.05.1973.

13. Патент 2340624 (РФ). Способ получения бетулина / В.А. Левданский, А.В. Левданский, Б.Н. Кузнецов. 10.12.2008.

14. Патент 2234936 (РФ). Способ получения бетулина из березовой коры / Ю.И. Стернин, С.В. Куликов. 27.08.2004.

15. Патент 2206572 (РФ). Способ выделения бетулинола / М.С. Борц, Е.Г. Николаева, И.С. Лаевский. 20.06.2003.

16. Patent 8197870 (US). Depolymerization extraction of compounds from birch bark / P.A. Krasutsky, I.V. Kolomitsyn, D.A. Krasutskyy. 12.06.2012.

17. Guoling Z., Weidong Y., Dan C. Simultaneous determination of betulin and betulinic acid in white birch bark using RP-HPLC // Journal of Pharmaceutical and Biomedical Analysis. 2007. Vol. 43, N3. Pp. 959-962.

18. Co M., Koskela P., Eklund-Aakergren P., King J. Pressurized liquid extraction of betulin and antioxidants from birch bark // Green Chemistry. 2009. Vol. 11, N5. Pp. 668-674.

19. Cao Dan, Zhao Guoling, Yan Weidong Solubilities of betulin in fourteen organic solvents at different temperatures // Journal of chemical engineering data. 2007. Vol. 52, N4. Pp. 1366-1368.

20. Кузнецова С.А., Скворцова Г.П., Калачева Г.С., Зайбель И.А., Ханчич О.А. Изучение состава этанольного экстракта бересты и его токсико-фармакологических свойств // Химия растительного сырья. 2010. №1. С. 137-141.

21. Кузнецова С.А., Кузнецов Б.Н., Веселова О.Ф., Кукина Т.П., Калачева Г.С., Скворцова Г.П., Редькина Е.С. Изучение состава гексанового экстракта бересты и его токсико-фармакологических свойств // Химия растительного сырья. 2008. №1. С. 45-49. 
Kuznetsova S.A. ${ }^{1,2^{*}}$, Skvortsova G.P. ${ }^{l}$, Maliar Iu.N. ${ }^{l}$, Skurydina E.S. ${ }^{l}$, Veselova O.F. ${ }^{3}$ EXTRACTION BETULIN FROM BIRCH BARK AND STUDY OF ITS PHYSICOCHEMICAL AND PHARMACOLOGICAL PROPERTIES

${ }^{I}$ Institute of Chemistry and Chemical Technology, Russian Academy of Sciences, Akademgorodok, 50/24, Krasnoyarsk, 660049 (Russia), e-mail: ksa@icct.ru

${ }^{2}$ Siberian Federal University, Svobodny Prospect, 79, Krasnoyarsk, 660041 (Russia)

${ }^{3}$ Krasnoyarsk State Medical University, Partizana Zhelezniaka, 1, Krasnoyarsk, 660022 (Russia)

It was extracted the products with yield about $40 \%$ by mas. of absolutely dry birch bark and the content in which 74 to $75 \%$ and $85-89 \%$ in the presence of sodium and potassium hydroxide, respectively. It was presented the one- step method of extraction high purity of betulin $97,7 \%$.

Betulin identified using of physicochemical methods: elemental analysis, IR and NMR spectroscopy, electron scanning microscopy, studied the thermal characteristics of betulin. It is shown that betulin exhibits gastroprotective, hepatoprotective and capillaries strengthening properties.

Keywords: birch bark, betulin, sodium hydroxide, potassium hydroxide, gastroprotective, hepatoprotective, capillaries strengthening properties.

\section{References}

1. Kislitsin A.N. Khimiia drevesiny, 1994, no. 3, pp. 3-28. (in Russ.).

2. Pokhillo N.D., Uvarova N.I. Khimiia prirodnykh soedinenii, 1988, no. 3, pp. 325-341. (in Russ.).

3. Zhuchenko A.G., Cherkasova A.I. Sbornik trudov SverdNIIP drevesiny, Moscow, 1969, no. 4, pp. 6-9. (in Russ.).

4. Wheeler J. Pharm. Jour., 1899, no. 1, pp. 494.

5. Holmes E.M. Pharm. Jour., 1921, no. 106, pp. 508.

6. Tolstikov A.G., Flekhter O.B., Shul'ts E.E., Baltina L.A. Khimiia v interesakh ustoichivogo razvitiia, 2005, no. 13, pp. 1-30. (in Russ.).

7. Tolstikov T.G., Sorokina I.V., Tolstikov G.A. Bioorganicheskaia khimiia, 2006, vol. 32, no. 1, pp. 42-55. (in Russ.).

8. Matsuda H., Ishikado A., Nishida N. Bioorganic \& Medicinal Chemistry Letters, 1998, vol. 8, pp. 2939-2944.

9. Abyshev A.Z., Agaev E.M., Guseinov A.B. Khimiko-farmatsevticheskii zhurnal, 2007, vol. 41, no. 8, pp. 22-26. (in Russ.).

10. Jääskelainen P. Paperi ja Puu., 1981, vol. 63, no. 10, pp. 599-603.

11. Hayek E.W.H., Jordis U., Moche W., Sauter F. Phytochemistry, 1989, vol. 28, no. 2, pp. 2229-2242.

12. Patent 382657 (USSR). 23.05.1973.

13. Patent 2340624 (RU). 10.12.2008.

14. Patent 2234936 (RU). 27.08.2004.

15. Patent 2206572 (RU). 20.06.2003.

16. Patent 8197870 (US). 12.06.2012.

17. Guoling Z., Weidong Y., Dan C. Journal of Pharmaceutical and Biomedical Analysis, 2007, vol. 43, no. 3, pp. 959-962.

18. Co M., Koskela P., Eklund-Aakergren P., King J. Green Chemistry, 2009. Vol. 11, N5. Pp. 668-674.

19. Cao Dan, Zhao Guoling, Yan Weidong. Journal of chemical engineering data, 2007. Vol. 52, N4. Pp. 1366-1368.

20. Kuznetsova S.A., Skvortsova G.P., Kalacheva G.S., Zaibel' I.A., Khanchich O.A. Khimiia rastitel'nogo syr'ia, 2010, no. 1, pp. 137-141. (in Russ.).

21. Kuznetsova S.A., Kuznetsov B.N., Veselova O.F., Kukina T.P., Kalacheva G.S., Skvortsova G.P., Red'kina E.S. Khimiia rastitel'nogo syr'ia, 2008, no. 1, pp. 45-49. (in Russ.).

\footnotetext{
* Corresponding author.
} 